\title{
Influence of season and low-level oestradiol immunoneutralization on episodic LH and testosterone secretion and testicular steroidogenic enzymes and steroidogenic acute regulatory protein in the adult ram
}

\author{
C. A. Price ${ }^{1}$, G. M. Cooke ${ }^{2 *}$ and L. M. Sanford ${ }^{3+}$ \\ ${ }^{1}$ Centre de recherche en reproduction animale, Faculté de médecine vétérinaire, Université de Montréal, St-Hyacinthe, Québec, \\ Canada J2S 7C6; ${ }^{2}$ Toxicology Research Division, Health Canada, Sir Frederick G. Banting Research Centre, 2202D1 Tunney's Pasture, \\ Ottawa, Ontario, Canada K1A 0L2; and ${ }^{3}$ Department of Animal Science, McGill University, Macdonald Campus, Ste Anne de Bellevue, \\ Québec, Canada H9X 3 V9
}

\begin{abstract}
The regulation of LH-dependent and -independent increases in testosterone secretion by key proteins in the testes of adult rams was investigated. Serial blood samples were collected from groups of four control and passively immunized (oestradiol antiserum for 3 weeks) rams and the animals were gonadectomized in either the non-breeding season (April) or the breeding season (September). LH pulse frequency and basal (interpulse) concentrations were several times greater $(P<0.01)$ in the breeding season than in the non-breeding season. Neither of these parameters nor LH pulse amplitude were affected by oestradiol immunization. Parameters of testosterone episodic secretion and response to an injection (i.v.) of $15 \mu \mathrm{g}$ NIH-LH-S25 were also greater $(P<0.05)$ in the breeding season and, with the exception of pulse frequency, in immunized rams versus controls. Substrate utilization established that testosterone biosynthesis was predominantly via the 5-ene pathway. Increases in blood testosterone concentration in the breeding season were associated with a fivefold higher $(P<0.01)$ activity of cytochrome $\mathrm{P} 45017 \alpha$-hydroxylase/C-17,20 lyase $\left(\mathrm{P}^{4} 50_{17 \alpha}\right)$ and a $65 \%$ higher $(P<0.05)$ relative amount of mRNA for cytochrome $\mathrm{P} 450$ cholesterol side-chain cleavage enzyme complex (P450scc) in the testis. Of the steroidogenic enzyme activities examined, only that for $17 \beta$-hydroxysteroid dehydrogenase (17 $\beta$-HSD) tended to be increased by oestradiol immunization. Blood concentrations of cholesterol lipoproteins and expression of the testicular low density lipoprotein receptor were not affected by season or immunization. The amount of steroidogenic acute regulatory protein (StAR) mRNA was $65 \%$ higher $(P<0.01)$ in the breeding season and $20 \%$ higher $(P<0.01)$ in immunized rams versus controls. These results indicate that greater LH stimulation may increase testosterone biosynthesis in the breeding season by increasing StAR mRNA (and presumably delivery of cholesterol to P450scc) and the activity of P450 and possibly that of P450scc (activity not measured). More moderate increases in StAR mRNA and 17ß-HSD activity may explain, in part, the increases in testosterone secretion with oestradiol immunization.
\end{abstract}

\section{Introduction}

Mammalian species inhabiting temperate regions usually show seasonal variation in testicular activity which, if pronounced enough, is associated with androgen-dependent changes in secondary sex characteristics and sexual and

*Correspondence.

†Present address: 111 Bruce Street, Suite 616, Kirkland, Québec, Canada H9H 4 B7.

Received 22 June 1999 aggressive behaviour (Lincoln, 1989). Testosterone production by the testes of some species such as sheep and reindeer is estimated to vary between five- and ten-fold during the year (Whitehead and West, 1977; Darbeïda and Brudieux, 1980). Higher production rates in the breeding season are made possible mainly by hypertrophy of Leydig cells (Lincoln, 1989; Hochereau-de Reviers et al., 1992). Greater steroidogenic capacity of Leydig cells in the ram testis corresponds to increased development of cellular organelles, including the mitochondria and smooth 
endoplasmic reticulum responsible for steroid biosynthesis (Lunstra and Schanbacher, 1988; Lincoln, 1989). Maintenance of the structural and functional integrity of Leydig cells involves primarily LH (Saez, 1994). In rams, LH pulse frequency (Sanford et al., 1984; Sanford and Baker, 1990) and basal (interpulse) LH concentration (Chase et al., 1988) are the most important release parameters regulating seasonal changes in testosterone secretion.

Although testosterone secretion in the ram is highly regulated by $\mathrm{LH}$, there is probably a moderating paracrine and autocrine control by a number of factors produced within the testis (Saez, 1994). One factor that may suppress testosterone secretion is oestradiol (Moger, 1980). In mature rams, oestradiol is thought to be produced mainly by Leydig cells and is present in the testes in extremely high concentrations (Bilinska et al., 1997; Hötzel et al., 1998). Oestradiol exerts a negative effect on gene expression and activity of cytochrome P450 17 $\alpha$-hydroxylase/C-17,20 lyase $\left(\mathrm{P}_{450_{17 \alpha}}\right)$ in rats (Wang et al., 1980; Majdic et al., 1996) by an oestrogen-receptor mediated action (Melner and Abney, 1980; Nozu et al., 1981) and is a competitive inhibitor of the activity of $3 \beta$-hydroxysteroid dehydrogenase $/ \Delta^{5}-\Delta^{4}$ isomerase ( $3 \beta-\mathrm{HSD})$ in mice (MA-10 Leydig tumour cells) (Freeman, 1985). Other studies indicate that oestrogen exerts similar actions in rams; low-level oestradiol immunoneutralization can result in three- to sixfold higher blood testosterone concentrations independently of increases in LH release and the number of LH receptors in the testis (Sanford, 1989; Sanford et al., 1991), although Leydig cells clearly become more responsive to LH (Sanford, 1985).

As is found in ruminants generally (Conley and Bird, 1997), testosterone synthesis in the ram testis involves the 5-ene pathway (Fields et al., 1980). In this pathway, pregnenolone formed from cholesterol by cytochrome P450 cholesterol side chain cleavage enzyme complex (P450scc) is metabolized to $17 \alpha$-hydroxypregnenolone and then to dehydroepiandrosterone (DHEA) by $\mathrm{P}^{2} 50_{17 \alpha}$. DHEA in turn is metabolized to androstenedione and then to testosterone by $3 \beta-\mathrm{HSD}$ and $17 \beta$-hydroxysteroid dehydrogenase (17 $\beta$-HSD), respectively. Investigations have not been undertaken in rams to determine how increases in testosterone secretion in the breeding season (mainly LH dependent) and with low-level oestradiol immunoneutralization (mainly LH independent) may relate to changes in the gene expression and activity of these four steroidogenic enzymes. Histochemical localization studies with deer have shown more intense staining for $3 \beta$ HSD in Leydig cells when blood testosterone concentrations are increased in the rut (Markwald et al., 1971; Lincoln, 1989).

The aim of the present study was to examine the effects of season and passive immunization against oestradiol on steady-state mRNA concentrations and activity of key proteins involved in: (i) testosterone biosynthesis (P450scc, $\mathrm{P}^{4} 0_{17 \alpha,} 3 \beta$-HSD and 17 $\beta$-HSD); and (ii) cholesterol substrate availability to the steroidogenic pathway (low density lipoprotein receptor, LDL-R; and steroidogenic acute regulatory protein, StAR). Testicular protein mRNA concentrations and activity, and blood lipoprotein concentrations were determined for adult control and immunized rams in relation to episodic LH and testosterone secretion in the non-breeding and breeding seasons.

\section{Materials and Methods}

\section{Animals}

Sixteen adult (6 years of age) DLS rams were used in this investigation. The DLS is a relatively new breed of sheep developed by crossbreeding Dorset, Leicester and Suffolk. Rams were entrained to natural photoperiod change (latitude $45^{\circ} 48^{\prime} \mathrm{N}$ ) during the experimental period, which began in mid-August and ended in early April. For DLS rams kept at this latitude, August and April represent months when testicular size and testosterone secretion are near, or at, yearly high and yearly low values, respectively (Sanford and Robaire, 1990). DLS ewes become seasonally anoestrus by the end of April (Fahmy and Dufour, 1986). Therefore, in the present study, experimental observations on rams were made in both the non-breeding and breeding seasons. The experiments were carried out in accordance with guidelines of the Canadian Council on Animal Care and the Animal Care Committee of McGill University.

\section{Blood and testicular tissue collection}

Beginning on August 17 (day 1) and again on March 15 (day 1), separate groups of four rams were passively immunized against oestradiol for 3 weeks. Other groups of four rams served as controls. On day 21 of immunization, a $7 \mathrm{ml}$ sample of blood was taken from a jugular vein of each ram every $20 \mathrm{~min}$ for $10 \mathrm{~h}$ (beginning at 09:30 h). After collection of the 25th sample, a single i.v. injection of $15 \mu \mathrm{g}$ NIH-LH-S25 was given to assess the testosterone response to a standardized physiological LH challenge. Melnyk et al. (1992) reported that injections of $10 \mu \mathrm{g}$ NIH-LH-S25 given to adult rams of similar body weight produced 'LH pulses' of an amplitude that was indistinguishable from those of endogenous LH pulses.

On day 23 of immunization, rams were gonadectomized $30 \mathrm{~min}$ after receiving an i.v. injection of the tranquillizer Ketamine $^{\circledR}(1 \mathrm{ml}$ per $50 \mathrm{~kg}$ body weight, $100 \mathrm{mg}$ ketamine hydrochloride $\mathrm{ml}^{-1}$ ) (Rogar/STB, London, ON) and a series of s.c. injections of the local anesthetic Xylocaine ${ }^{\circledR}(15 \mathrm{ml}, 20 \mathrm{mg}$ lidocaine hydrochloride plus $0.01 \mathrm{mg}$ adrenaline $\mathrm{ml}^{-1}$ ) (Astra Pharmaceuticals, Mississauga, ON) in the scrotal neck area. As the testes were removed, a number of samples of testicular tissue (1-2 g) were taken for each ram and frozen on dry ice. Tissue for RNA extraction was placed immediately into $4 \mathrm{~mol}$ guanidinium isothiocyanate $\mathrm{l}^{-1}$ containing $0.12 \mathrm{~mol} \beta$ mercaptoethanol $1^{-1}$ before it was frozen. All samples of testicular tissue were stored at $-70^{\circ} \mathrm{C}$. Testicular mass and body weight were recorded at the time of gonadectomy.

\section{Oestradiol antiserum development and passive immunization}

The oestradiol antibody used in passive immunization had been developed in gonadectomized adult DLS rams. Three rams were actively immunized against oestradiol-6(O-carboxymethyl)oxime-BSA conjugate as described by Sanford (1987a) and several litres of antisera were harvested and stored frozen $\left(-20^{\circ} \mathrm{C}\right)$. In the present study, individual collections of antisera were thawed, pooled and treated with 
charcoal-dextran (10:1 (w/w); $550 \mathrm{mg}$ per $200 \mathrm{ml}$ serum) to remove endogenous steroids. After $6 \mathrm{~h}$ of incubation at $4^{\circ} \mathrm{C}$, charcoal-dextran was removed from the pooled antiserum by centrifugation (twice at $600 \mathrm{~g}$ for $20 \mathrm{~min}$ ) and passage through progressively smaller millipore filters (0.45 and $0.22 \mu \mathrm{m})$. The titre of oestradiol antibody in the pool, defined as the dilution of serum that bound $50 \%$ of added $\left[2,4,6,7,16,17-{ }^{3} \mathrm{H}\right]$ oestradiol (10700 c.p.m. or $18 \mathrm{pg}$ ) (New England Nuclear, Mississauga, $\mathrm{ON}$ ) in an overnight incubation at $4^{\circ} \mathrm{C}$, was $1: 4500$. The antiserum was specific for oestradiol, crossreacting only slightly with oestrone (15\%).

Passively immunized rams were injected with sufficient oestradiol antiserum to develop an antibody titre of about 1:200 within 1 week, as described by Sanford (1987a) and Sanford et al. (1991). Antiserum $(60 \mathrm{ml})$ was injected into the jugular vein on day 1 of immunization, and then again every 3-4 days for 3 weeks (total of seven immunizations). The amount of antiserum injected into rams in the breeding season was increased to $120 \mathrm{ml}$ per injection in week 2 to take into account the $50-100 \%$ higher oestradiol concentration in peripheral blood at this time of the year (Sanford et al., 1993).

\section{Testosterone binding by oestradiol antiserum}

The ability of oestradiol antibody to bind testosterone under in vivo conditions (for example, in serum at the low titre established in the passively immunized rams) was evaluated to examine the possibility that any increase in testosterone concentration with immunization was the result of greater retention of testosterone within the blood circulation (Webb et al., 1984) as well as increased secretion (Schanbacher et al., 1987). Negligible crossreaction of the oestradiol antiserum with testosterone $(<2 \%)$ under in vitro conditions (for example at high antibody dilution in the absence of other steroids) may not hold true in vivo. This was evaluated by determining: (i) the percentage binding of labelled testosterone in serum pools representing the first $8 \mathrm{~h}$ of blood sampling from immunized and control rams in the breeding season; and (ii) the ability of oestradiol to displace labelled testosterone in these same samples. Binding of $\left[1,2,6,7-{ }^{3} \mathrm{H}\right]$ testosterone (16000 c.p.m. or $48 \mathrm{pg}$ ) (New England Nuclear, Mississauga, ON) by $100 \mu \mathrm{l}$ undiluted serum was determined in an overnight incubation at $4^{\circ} \mathrm{C}$. Radioactivity in the serum-bound fraction (supernatant) was counted after free and bound fractions were separated by charcoal-dextran. The displacement of testosterone binding by oestradiol was assessed by first incubating $200 \mu \mathrm{l}$ serum with labelled testosterone overnight at $4^{\circ} \mathrm{C}$ and removing the free steroid with charcoal-dextran. The supernatant $(100 \mu \mathrm{l})$ was then incubated overnight at $4^{\circ} \mathrm{C}$ with $100 \mu \mathrm{l}$ PBS $(1 \%$ $(\mathrm{w} / \mathrm{v})$ gelatin) containing $3.2,32.0$ or $320.0 \mathrm{ng}$ oestradiol. Free steroid was removed by charcoal-dextran and radioactivity remaining in the supernatant was counted.

\section{Blood hormone assays and pulse analysis}

Blood sera obtained during the $10 \mathrm{~h}$ collection periods were assayed for LH (Niswender et al., 1969) and testosterone (Sanford, 1985) using double-antibody radioimmunoassay. The primary antiserum in the LH assay, provided by N. C. Rawlings (University of Saskatchewan, Saskatoon, SK; NCR no. 7) and validated for this assay system (Sanford, 1987a), was used at the initial dilution of 1:80000. The reference preparation was NIH-LH-S24. The minimum detectable concentrations of LH and testosterone with assay at the serum volumes indicated were $0.08 \mathrm{ng} \mathrm{ml}^{-1}$ $(200 \mu \mathrm{l})$ and $0.45 \mathrm{ng} \mathrm{ml}^{-1}(20 \mu \mathrm{l})$, respectively. Intra- and interassay coefficients of variation were all less than $12 \%$.

Patterns of episodic LH and testosterone secretion were characterized from hormone concentrations obtained over the first $8 \mathrm{~h}$ of serial blood collection (Sanford et al., 1993). Briefly, increases in concentration were identified as pulses when: (i) peak values occurred within 40 (LH) or 60 (testosterone) min of the preceding basal value; (ii) the increase exceeded twice the minimum detectable concentration of the assay; and (iii) the increase was greater than two standard deviations associated with duplicate estimates of the preceding basal value. Pulse frequency is the total number of pulses occurring over the $8 \mathrm{~h}$ period, and pulse amplitude is the mean of the differences between peak and preceding basal concentrations. Basal (interpulse) concentration is the mean of all values not associated with a pulse or pulses. The total testosterone response to $\mathrm{LH}$ injection was determined by measuring the area under the $2 \mathrm{~h}$ response curve above concentration at time 0 .

\section{Testicular steroidogenic enzyme activities}

The radiolabelled steroids $\left[7-{ }^{3} \mathrm{H}\right]$ pregnenolone $(25.0 \mathrm{Ci}$ $\mathrm{mmol}^{-1}$ ), [1,2,6,7-3 $\left.\mathrm{H}\right]$ progesterone (109.5 $\left.\mathrm{Ci} \mathrm{mmol}^{-1}\right)$, [1,2,6,7$\left.{ }^{3} \mathrm{H}\right]$-dehydroepiandrosterone (DHEA) $\left(89.2 \mathrm{Ci} \mathrm{mmol}^{-1}\right)$ and $\left[7-{ }^{3} \mathrm{H}\right]$ androstenedione $\left(24.5 \mathrm{Ci} \mathrm{mmol}^{-1}\right)$ were obtained from New England Nuclear (Mississauga, ON). The unlabelled carrier steroids pregnenolone, progesterone, $17 \alpha$-hydroxypregnenolone, $17 \alpha$-hydroxyprogesterone, DHEA, 4-androstenedione, 5 -androstene-3 $\beta, 17 \beta$-diol and testosterone were obtained from Steraloids Inc. (Wilton, NH). Nicotinamide cofactors came from Sigma Chemical Co. (St Louis, MO). Organic solvents were obtained from BDH (Montreal, QC) and plastic coated silica gel thin-layer chromatography plates from Merck (Darmstadt). All other chemicals were of reagent grade.

At the time of assay, the testes were thawed and homogenized in a motor-driven Potter-Elvejhem homogenizer in Tris- $\mathrm{HCl}\left(50 \mathrm{mmol} \mathrm{l}^{-1}\right)$ buffer, $\mathrm{pH} 7.5$, containing sucrose $\left(0.25 \mathrm{~mol} \mathrm{l}^{-1}\right), \mathrm{KCl}\left(25 \mathrm{mmol} \mathrm{l}^{-1}\right), \mathrm{MgCl}_{2}\left(5 \mathrm{mmol} \mathrm{l}^{-1}\right)$ and mercaptoethanol $\left(7 \mathrm{mmol} \mathrm{l}^{-1}\right)$. The homogenate was centrifuged at $10000 \mathrm{~g}$ for $10 \mathrm{~min}$ at $4^{\circ} \mathrm{C}$ (Beckman L7 Ultracentrifuge, Beckman Instruments, Montreal, QC) and the supernatant re-centrifuged under the same conditions to yield a postmitochondrial supernatant. The microsomal fraction was obtained by centrifuging the post-mitochondrial supernatant at $176000 \mathrm{~g}$ for $1 \mathrm{~h}$ at $4^{\circ} \mathrm{C}$. Microsomes were resuspended in Tris- $\mathrm{HCl}$ buffer, $\mathrm{pH} 7.5$, and used immediately for assessment of steroidogenic enzyme activities. Protein was estimated using the method of Lowry et al. (1951).

Radiometric enzyme assays were conducted according to 
a modified method of Cooke (1991) and Cooke et al. (1998). For 17-hydroxylase activity, aliquants of microsomal fraction were added to Tris- $\mathrm{HCl}$ buffer, $\mathrm{pH} 7.5(3 \mathrm{ml})$, containing pregnenolone $\left(1 \mu \mathrm{mol} \mathrm{l}{ }^{-1}, 40000\right.$ c.p.m. $\left.{ }^{3} \mathrm{H}\right)$ (1 c.p.m. $=0.0167$ $\mathrm{Bq}$ ) and NADPH and $\mathrm{NAD}^{+}$(both at $0.25 \mathrm{mmol}^{-1}$ ) at $37^{\circ} \mathrm{C}$ in a reciprocating water bath. After 30,60 and $90 \mathrm{~min}, 1.0 \mathrm{ml}$ was withdrawn and transferred to a glass screw-cap test tube containing hexane $(5 \mathrm{ml})$ and carrier steroids (pregnenolone, progesterone, 17 $\alpha$-hydroxypregnenolone, 17 $\alpha$-hydroxyprogesterone, DHEA, 4-androstenedione, 5-androstene$3 \beta, 17 \beta$-diol and testosterone; $30 \mu \mathrm{g}$ each). The tubes were vortexed vigorously to terminate the reactions and extract the steroids, and were centrifuged $(800 \mathrm{~g}$ for $10 \mathrm{~min}$ ) to achieve phase separation. The organic phase was transferred to conical tubes and evaporated (Savant, Speedvac Plus, Fisher Scientific, Ottawa, ON). The residue was applied to plastic-coated thin-layer plates (Whatman PE SIL G) which were developed in a two-dimensional system to separate the steroids. The first dimension was chloroform-acetone $(9: 1$, $\mathrm{v} / \mathrm{v})$ and the second dimension was hexane-ethyl acetate $(5.0: 3.5, \mathrm{v} / \mathrm{v})$ (Hurden et al., 1984). Carrier steroids were visualized by ultraviolet illumination and exposure to iodine vapour. The regions corresponding to the carrier steroids were excised and quantified by scintillation counting. The combined quantities of radiolabelled 17 $\alpha$-hydroxypregnenolone, 17 $\alpha$-hydroxyprogesterone, DHEA and 4-androstenedione were used to determine $\mathrm{P} 450_{17 \alpha}$ activity (testosterone and other steroids were produced in negligible quantities). The same methodology was used to determine $\mathrm{P}^{4} 50_{17 \alpha}$ activity using progesterone as the steroid substrate $\left(1 \mu \mathrm{mol} \mathrm{l}{ }^{-1}, 40000\right.$ c.p.m. $\left.{ }^{3} \mathrm{H}\right)$ and NADPH $\left(0.25 \mathrm{mmol}^{-1}\right)$ as cofactor (Cooke et al., 1998). 3 $\beta$-HSD activity was determined by combining the amounts of 4-ene-3-oxosteroids in pregnenolone incubations and was verified in assays using DHEA as the steroid substrate $\left(1 \mu \mathrm{mol} \mathrm{l}{ }^{-1}, 40000\right.$ c.p.m. $\left.{ }^{3} \mathrm{H}\right)$ and $\mathrm{NAD}^{+}\left(0.25 \mathrm{mmol}^{-1}\right)$ as the cofactor, and $\mathrm{pH}$ of the incubation was 8.4. The carrier steroids were DHEA, 5 -androstene-3 $\beta, 17 \beta$-diol, 4-androstenedione and testosterone, and steroid separation was achieved using unidimensional thin-layer chromatography (chloroform-acetone, 9:1 (v/v), run once). The only product was 4-androstenedione. Identical methods were used to determine $17 \beta-H S D$ activity except that 4-androstenedione was the steroid substrate $\left(1 \mu \mathrm{mol} \mathrm{l}{ }^{-1}, 40000\right.$ c.p.m. $\left.{ }^{3} \mathrm{H}\right), \mathrm{NADPH}\left(0.25 \mathrm{mmol}^{-1}\right)$ was the cofactor, and the $\mathrm{pH}$ of the reaction was 7.5. The quantity of testosterone produced was used to determine activity.

Optimal conditions for all enzymes were determined with respect to steroid substrate, cofactor and protein concentrations and linearity of reaction with time. Incubation conditions were chosen that maintained the conversion of a saturating concentration of steroid substrate to less than $15 \%$ in accordance with the criteria for enzyme kinetic analysis (Cleland, 1967). Reaction rates were obtained by linear regression analysis $(r>0.95)$.

\section{Testicular steroidogenic enzyme mRNA concentration}

Testicular tissue was thawed and homogenized in $4 \mathrm{~mol}$ guanidine isothiocyanate $1^{-1}$ containing $0.12 \mathrm{~mol}$ $\beta$-mercaptoethanol $\mathrm{l}^{-1}$. Total RNA was isolated by centrifugation for $21 \mathrm{~h}$ at $174000 \mathrm{~g}$ on a cushion of $5.7 \mathrm{~mol}$ cesium chloride $1^{-1}$. The pellet was resuspended in $3 \mathrm{~mol}$ sodium acetate $1^{-1}$, precipitated twice with ethanol and quantified by measuring absorbance at $260 \mathrm{~nm}$.

For northern blot analysis, total RNA $(20 \mu \mathrm{g})$ was size fractionated on a $1 \%(\mathrm{v} / \mathrm{v})$ formaldehyde-agarose gel. The RNA was transferred overnight by capillary action onto a nylon membrane (Hybond-N Nylon, $0.45 \mu$, cat. RPN.1510N; Amersham, Oakville, ON) which was subsequently crosslinked in a commercial UV chamber (Bio Rad, Mississauga, $\mathrm{ON})$. Membranes were incubated for $2 \mathrm{~h}$ in prehybridization solution containing $10 \%(\mathrm{w} / \mathrm{v})$ dextran sulfate, $5 \times$ saline-sodium phosphate-EDTA (SPPE), $5 \times$ Denhardt's solution, $0.5 \%(\mathrm{w} / \mathrm{v})$ SDS and herring sperm DNA $(200 \mathrm{mg}$ $\left.\mathrm{ml}^{-1}\right)$. Hybridization with labelled cDNA probes was performed overnight at $65^{\circ} \mathrm{C}$. After hybridization, membranes were washed in $2 \times \mathrm{SSPE}-0.1 \%(\mathrm{w} / \mathrm{v})$ SDS twice at room temperature and twice at $65^{\circ} \mathrm{C}$. The labelled membranes were exposed to Kodak X-Omat film (Kodak Canada Inc., Toronto, $\mathrm{ON}$ ) at $-70^{\circ} \mathrm{C}$ in the presence of an intensifying screen for 1-5 days. Membranes were stripped and rehybridized to a labelled $28 \mathrm{~S}$ ribosomal cDNA probe as internal control. The relative abundance of signal was quantified by densitometry (Collage Analysis; Fotodyne Inc., Hartland, WI). The density of hybridization signals was corrected for loading using hybridization to 28S, and these corrected data were expressed relative to a control ram sample that was included in the two blots required.

mRNA concentrations were determined for P450scc (activity not measured) and $\mathrm{P}^{4} 50_{17 \alpha}$ (activity differed with season). The bovine cDNA probes for P450scc (1.7 kb insert) and $\mathrm{P}_{450_{17 \alpha}}(2 \mathrm{~kb}$ insert) were a gift from Dr M. R. Waterman (Vanderbilt University School of Medicine, Nashville, TN). These cDNA contain the complete coding sequences for each enzyme (John et al., 1984; Zuber et al., 1986). The probes were labelled with $\left[\alpha-{ }^{32} \mathrm{P}\right] \mathrm{dCTP}$ by random primer extension (Boehringer Mannheim, Laval, QC) to a specific activity of 1.5-3.0 $\times 10^{9}$ d.p.m. $\mu \mathrm{g}^{-1}$. Labelled probes were purified by centrifugation through a minicolumn using Wizard PCR Preps DNA purification (Promega, Ottawa, ON).

\section{Blood cholesterol and testicular LDL-R and StAR mRNA}

Total cholesterol concentration in peripheral blood $(8 \mathrm{~h}$ serum pools) of rams was measured with the commercially prepared A-Gent ${ }^{\circledR}$ cholesterol test kit (Abbott Laboratories, Montreal, QC). Combined very low and low density lipoprotein (VLDL and LDL) and high density lipoprotein (HDL) fractions were quantified specifically by measuring cholesterol content of serum HDL after the VLDL and LDL fraction was precipitated with A-Gent ${ }^{\circledR}$ HDL reagent. The difference between total and HDL cholesterol concentrations was taken as VLDL and LDL concentration.

Testicular mRNA concentrations for the LDL-R and StAR protein were assessed by slot blot analysis, loading approximately $6 \mu \mathrm{g}$ sample per well. The bovine LDL-R cDNA was generated in this laboratory (Soumano and Price, 1997) and corresponds to +643 to +792 (from the start codon) 
Table 1. Parameters of episodic LH and testosterone secretion in control and oestradiol-immunized rams on day 21

\begin{tabular}{|c|c|c|c|c|}
\hline \multirow[b]{2}{*}{ Hormonal parameter } & \multicolumn{2}{|c|}{ Non-breeding season } & \multicolumn{2}{|c|}{ Breeding season } \\
\hline & Control rams & Immunized rams & Control rams & Immunized rams \\
\hline \multicolumn{5}{|l|}{$\mathrm{LH}$} \\
\hline Mean concentration $\left(\mathrm{ng} \mathrm{ml} \mathrm{ml}^{-1}\right)$ & $0.29 \pm 0.14^{\mathrm{a}}$ & $0.17 \pm 0.04^{\mathrm{a}}$ & $0.83 \pm 0.10^{\mathrm{b}}$ & $0.88 \pm 0.13^{\mathrm{b}}$ \\
\hline Basal concentration (ng ml-1) & $0.23 \pm 0.10^{\mathrm{a}}$ & $0.15 \pm 0.02^{\mathrm{a}}$ & $0.51 \pm 0.05^{\mathrm{b}}$ & $0.56 \pm 0.12^{\mathrm{b}}$ \\
\hline Pulse frequency (number per $8 \mathrm{~h}$ ) & $0.7 \pm 0.7^{\mathrm{a}}$ & $0.3 \pm 0.3^{\mathrm{a}}$ & $3.3 \pm 0.3^{\mathrm{b}}$ & $3.3 \pm 0.3^{b}$ \\
\hline Pulse amplitude $\left(\mathrm{ng} \mathrm{ml}^{-1}\right)$ & $0.62(1)$ & $0.70(1)$ & $1.04 \pm 0.24^{\mathrm{a}}$ & $1.08 \pm 0.05^{\mathrm{a}}$ \\
\hline \multicolumn{5}{|l|}{ Testosterone } \\
\hline Mean concentration (ng ml-1) & $1.9 \pm 0.6^{\mathrm{a}}$ & $2.8 \pm 1.1^{\mathrm{a}}$ & $11.5 \pm 0.9^{b}$ & $20.1 \pm 2.1^{\mathrm{c}}$ \\
\hline Basal concentration $\left(\mathrm{ng} \mathrm{m}^{-1}\right)$ & $0.9 \pm 0.2^{\mathrm{a}}$ & $1.9 \pm 0.3^{b}$ & $5.7 \pm 0.9^{c}$ & $10.3 \pm 1.1^{\mathrm{d}}$ \\
\hline Pulse frequency (number per $8 \mathrm{~h}$ ) & $0.7 \pm 0.7^{\mathrm{a}}$ & $0.3 \pm 0.3^{\mathrm{a}}$ & $3.8 \pm 0.5^{\mathrm{b}}$ & $3.5 \pm 0.5^{\mathrm{b}}$ \\
\hline Pulse amplitude $\left(\mathrm{ng} \mathrm{ml}^{-1}\right)$ & $5.3(1)$ & $14.7(1)$ & $14.2 \pm 1.9^{\mathrm{a}}$ & $24.6 \pm 3.4^{\mathrm{b}}$ \\
\hline
\end{tabular}

Blood samples were taken from the jugular vein every $20 \mathrm{~min}$ for $8 \mathrm{~h}$.

Data represent the mean \pm SEM of three (non-breeding, control) or four rams, unless indicated otherwise in parentheses.

abcdWithin rows, means with different superscripts are significantly different $(P<0.05)$.

of the bovine sequence reported by Russell et al. (1984). The full-length cDNA encoding mouse StAR (Clark et al., 1994) was provided by D. Stocco (Texas Tech University, Health Sciences Center, Lubbock, TX).

\section{Statistical analyses}

The statistical significance of season and immunization differences was determined by two-way ANOVA (SAS, 1989). When main effects or the season $\times$ immunization interaction were significant $(P<0.05)$, group means were compared using the predicted difference option of least-squares means. When appropriate, a logarithmic transformation was applied to the data for analysis to normalize variances between treatment groups. Data from one of the control rams (nonbreeding season) were excluded from these analyses because of abnormally high LH release. Mean and basal LH concentrations and LH pulse frequency in this ram were more than six- and twofold greater than in other rams in the non-breeding and breeding seasons, respectively.

Blood parameters of episodic LH and testosterone secretion were correlated with selected testicular mRNA and enzyme activity measurements by linear regression analysis. Pearson or Spearman (pulse frequency) correlation coefficients were calculated on data combined for all four groups of rams.

\section{Results}

\section{Body weight and testicular mass}

Body weight and paired testes mass of rams were greater (season, $P<0.05)$ in the breeding season $(90.9 \pm 2.4 \mathrm{~kg}$, $753 \pm 38 \mathrm{~g})$ than in the non-breeding season $(75.7 \pm 3.5 \mathrm{~kg}$, $586 \pm 43 \mathrm{~g})$. However, testes mass as a percentage of body weight was the same in both seasons (breeding season,
$0.83 \pm 0.04 \%$; non-breeding season, $0.78 \pm 0.06 \%$ ). None of these measurements was affected by oestradiol immunization.

\section{Blood parameters of episodic LH and testosterone secretion}

Mean and basal LH concentrations and LH pulse frequency in rams were three- to sixfold higher (season, $P<0.01)$ in the breeding season than in the non-breeding season. Oestradiol immunization did not influence any of the parameters of LH release in either season (Table 1). Parameters of testosterone secretion were also greater (season, $P<0.05$ ) in the breeding season and, with the exception of pulse frequency, were increased (immunization, $P<0.05$ ) by oestradiol immunization. However, increases in mean testosterone concentration in immunized versus control rams were apparent only in the breeding season (season $\times$ immunization, $P<0.05$ ) (Table 1$)$.

Total testosterone response to $\mathrm{LH}$ injection was more than 2.5-fold greater (season, $P<0.01$ ) in the breeding season than in the non-breeding season. Total response in immunized rams was twice that (immunization, $P<0.01$ ) in control rams in both seasons (Fig. 1c), mainly due to greater increments in testosterone concentration at 40,60 and $80 \mathrm{~min}$ (Fig. 1a,b).

\section{Testosterone binding by oestradiol antiserum}

A near doubling $(P<0.01)$ in mean testosterone concentration with oestradiol immunization in the breeding season (control rams, $11.5 \pm 0.9 \mathrm{ng} \mathrm{ml}^{-1}$; immunized rams, $20.1 \pm 2.1 \mathrm{ng} \mathrm{ml}^{-1}$ ) was not associated with greater binding of testosterone tracer in serum of immunized rams $(67.8 \pm 0.6 \%$ versus $62.0 \pm 2.3 \%$ for controls $)$. Tritiated testosterone was not displaced from serum by the addition of $3.2 \mathrm{ng}$ oestradiol, but $32 \mathrm{ng}$ oestradiol displaced $35.6 \pm 1.9 \%$ and $25.3 \pm 8.2 \%$ of the tracer bound to control and immune sera, respectively. Addition of $320 \mathrm{ng}$ oestradiol displaced 

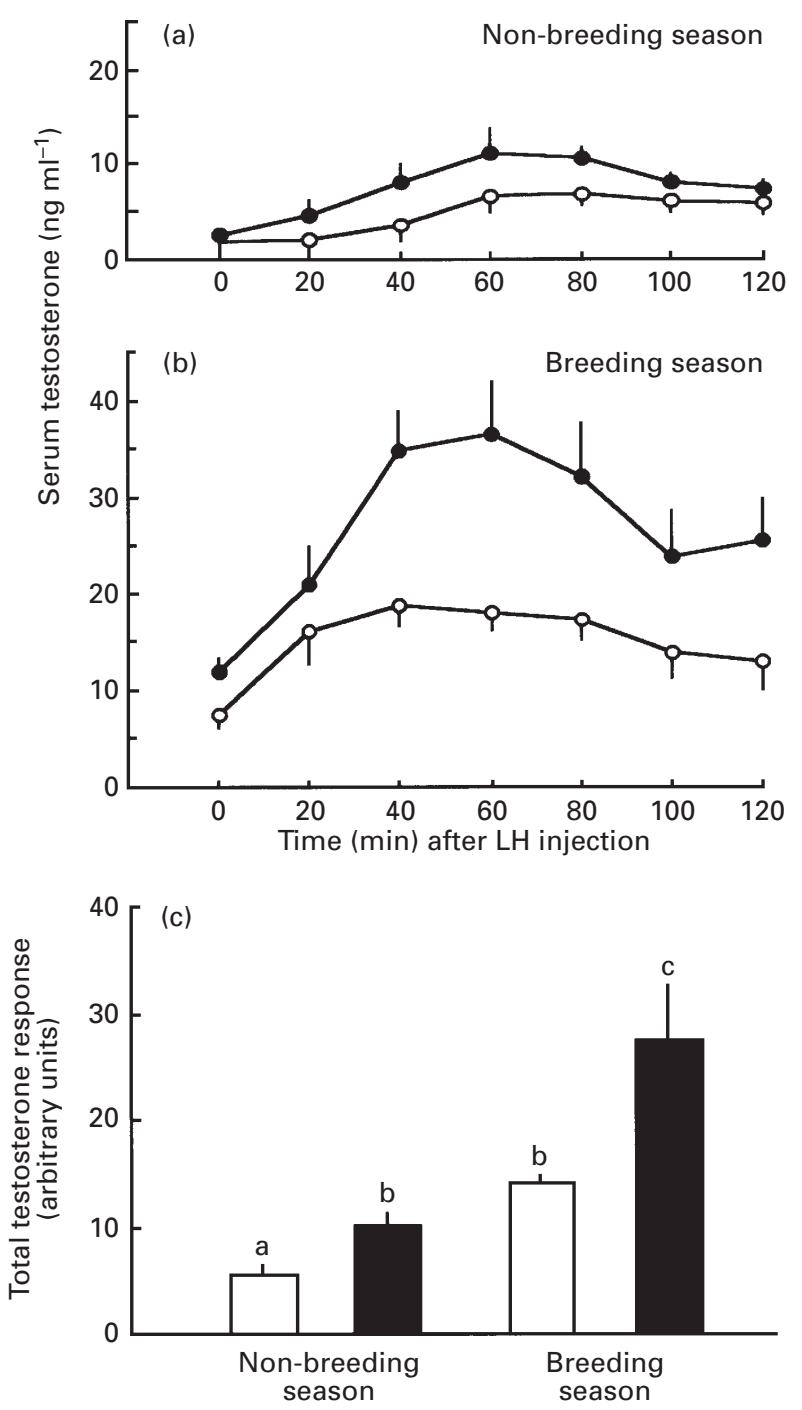

Fig. 1. Serum testosterone concentrations at $20 \mathrm{~min}$ intervals $(\mathrm{a}, \mathrm{b})$ and total testosterone response (area under curve above time 0 concentration) (c) for control $(\bigcirc, \square)$ and oestradiol-immunized $(\bullet, \square)$ rams given an i.v. injection of $15 \mu \mathrm{g}$ NIH-LH-S25 (day 21) in the non-breeding and breeding seasons. Means ( \pm SEM) represent three (controls, non-breeding season) or four rams. Different letters indicate significant $(P<0.05)$ differences in total testosterone response between groups.

$68.7 \pm 5.3 \%$ and $77.0 \pm 0.8 \%$ of tracer bound to control and immune sera, respectively. Differences between treatment groups were not statistically significant (Student's $t$ test).

\section{Activity of testicular steroidogenic enzymes}

Substrate utilization established that pregnenolone metabolism by ram testis microsomes proceeded predominantly through the 5-ene route; $40-50 \%$ of the pregnenolone appeared as $17 \alpha$-hydroxypregnenolone and DHEA. Less than $5 \%$ of the pregnenolone was metabolized through the 4-ene route to progesterone and $17 \alpha$ -
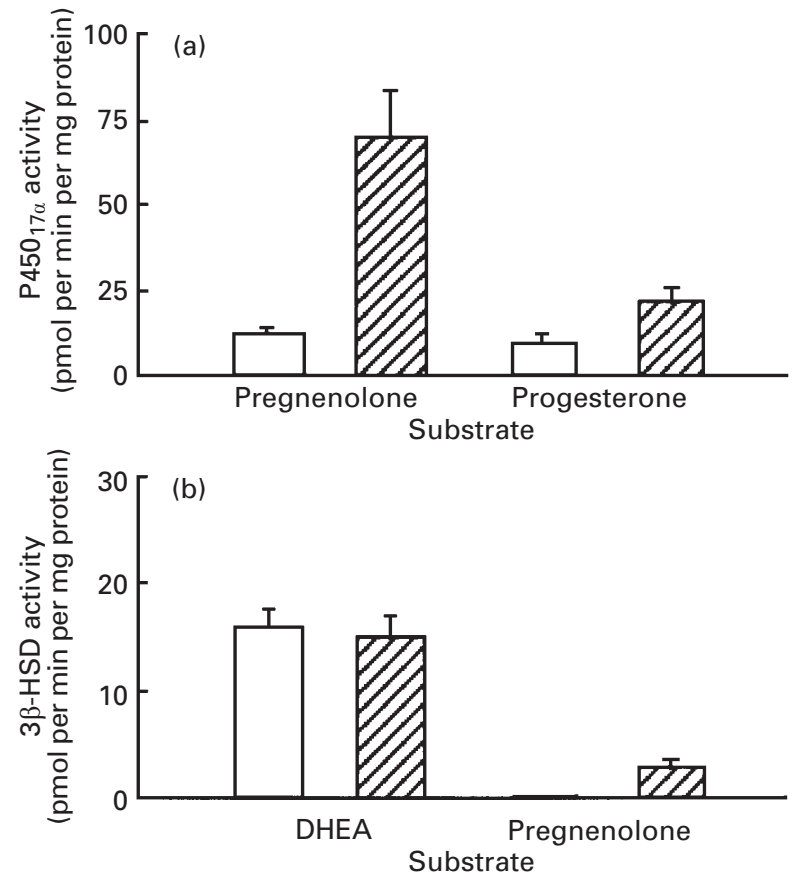

Fig. 2. Activity of $P 450_{17 \alpha}$ with pregnenolone or progesterone as substrate (a) and of $3 \beta$-hydroxysteroid dehydrogenase $/ \Delta^{5}-\Delta^{4}$ isomerase (3 $\beta$-HSD) with dehydroepiandrosterone (DHEA) or pregnenolone as substrate (b) in testicular tissue taken from control and oestradiol-immunized rams (day 23). Means ( \pm SEM) represent seven ( $\square$, non-breeding season) or eight $(\square$, breeding season) rams.

hydroxyprogesterone. When progesterone rather than pregnenolone was supplied as substrate, the activity of $\mathrm{P}_{450} 0_{17 \alpha}$ was reduced by $30 \%$ and $70 \%$ in the non-breeding and breeding seasons, respectively (Fig. 2a). Activity of $3 \beta$ HSD with pregnenolone rather than DHEA as substrate was undetectable in the non-breeding season and was only $20 \%$ of the activity with DHEA in the breeding season (Fig. 2b).

Activity of $\mathrm{P}^{4} 50_{17 \alpha}$ (pregnenolone as substrate) was more than fivefold greater (season, $P<0.01$ ) in the breeding season than in the non-breeding season (Fig. 3a). When activity was expressed as pmol per min per $g$ tissue or per testis rather than mg microsomal protein, $\mathrm{P}_{450_{17 \alpha}}$ activity was still fourfold greater (season, $P<0.01$ ) in the breeding season. In contrast, the activity of $3 \beta-H S D$ (DHEA as substrate) expressed either on a protein or testis basis was unchanged with season (Fig. 3b). When expressed as per $g$ tissue, $3 \beta$ HSD activity was about $35 \%$ lower (season, $P<0.05$ ) in the breeding season $\left(102 \pm 14 \mathrm{pmol} \mathrm{min}^{-1}\right)$ than in the non-breeding season $\left(164 \pm 21 \mathrm{pmol} \mathrm{min}^{-1}\right)$, as was the concentration of microsomal protein. The activity of $17 \beta$ HSD did not differ between seasons (Fig. 3c). Immunization against oestradiol did not significantly affect the activity of any of the steroidogenic enzymes examined, although $17 \beta$ HSD activity expressed on a protein basis tended to be higher in immunized rams $\left(57 \pm 7 \mathrm{pmol} \mathrm{min}^{-1}\right)$ than in

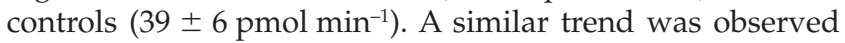
when $17 \beta-H S D$ activity was expressed on a per $g$ tissue or testis basis. 

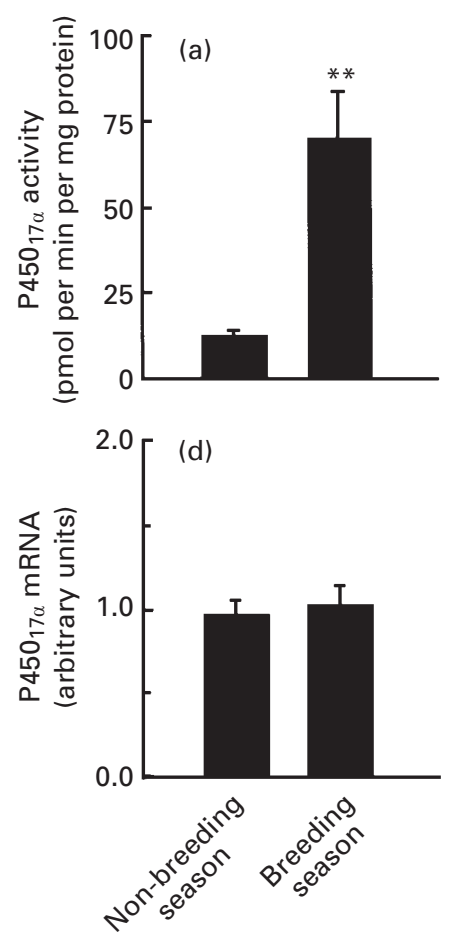
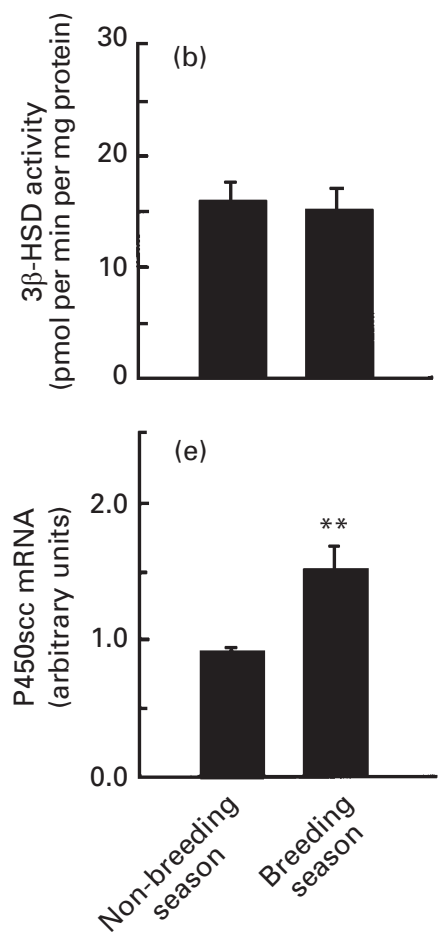

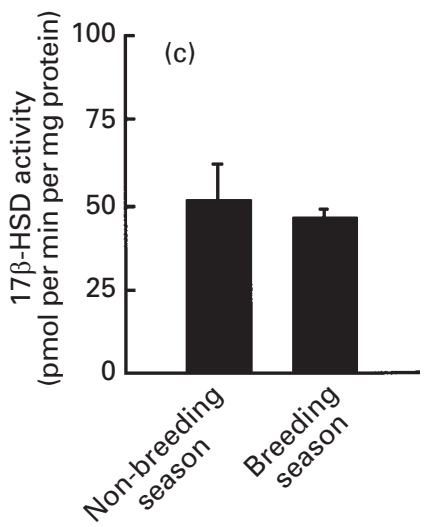

Fig. 3. Activity of $P 450_{17 \alpha}$ with pregnenolone as substrate (a), $3 \beta$-hydroxysteroid dehydrogenase $/ \Delta^{5}-\Delta^{4}$ isomerase

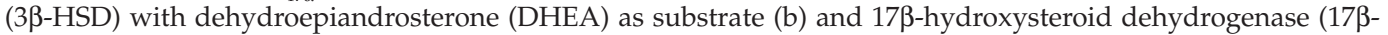
HSD) with androstenedione as substrate (c), and relative amount of mRNA of $\mathrm{P}^{4} 50_{17 \alpha}$ (d) and P450scc (e) in testicular tissue taken from control and oestradiol-immunized rams (day 23). Estimates of mRNA abundance were corrected for loading (pixel density of target probe divided by pixel density of 28S rRNA probe) and are expressed relative to a control sample included in all blots. Means ( \pm SEM) represent seven (non-breeding season) or eight (breeding season) rams. Asterisks indicate significant $(* * P 0.01)$ differences between seasons.

\section{mRNA abundance for testicular steroidogenic enzymes}

The relative amount of P450scc mRNA (Fig. 3e) in ram testes was $65 \%$ higher (season, $P<0.05$ ) in the breeding season than in the non-breeding season. The relative abundance of $\mathrm{P}_{450_{17 \alpha}}$ (Fig. 3d) was not different between seasons. Oestradiol immunization did not affect the amount of mRNA for either of these enzymes.

\section{Blood cholesterol concentrations and testicular mRNA abundance for LDL-R and StAR}

Serum concentrations of total cholesterol in rams averaged $52.3 \pm 3.0 \mathrm{mg} \mathrm{dl}^{-1}$, of which slightly more (Student's $t$-test, $P<0.05)$ was in the form of VLDL and LDL $\left(28.7 \pm 2.1 \mathrm{mg} \mathrm{dl}^{-1}\right.$, $54 \%)$ than HDL $\left(23.5 \pm 1.2 \mathrm{mg} \mathrm{dl}^{-1}, 46 \%\right)$. Neither combined VLDL and LDL nor HDL were affected by season (Fig. $4 a, b$ ) or immunization. The same was true for relative amount of mRNA for the LDL-R in the testis (Fig. 4c). However, the abundance of StAR mRNA was affected by both season and immunization; it was $65 \%$ higher (season, $P<0.01$ ) in the breeding season compared with the non-breeding season (Fig. $4 \mathrm{~d}$ ), and was $20 \%$ greater (immunization, $P<0.01$ ) in immunized rams than in controls in both seasons (for example breeding season, $1.05 \pm 0.04$ arbitrary units versus $0.87 \pm 0.06$ arbitrary units for controls).

\section{Correlation of blood hormone with testicular protein measurements}

Three parameters of episodic LH release (mean and basal concentrations, and pulse frequency) were consistently correlated with testicular mRNA or activity of StAR, P450scc and $\mathrm{P}_{45} 0_{17 \alpha}$ (Table 2). The correlations of LH parameters with $\mathrm{P}^{2} 0_{17 \alpha}$ activity were all highly significant $(r=0.81-0.90$, $P<0.001)$. StAR mRNA and $P 450_{17 \alpha}$ activity were, in turn, correlated with parameters of episodic testosterone secretion (mean, basal and stimulated concentrations) (Table 3). Most of these correlations were highly significant $(r=0.82-0.86$, $P<0.001)$.

\section{Discussion}

This is the first study to demonstrate that increases in testosterone secretion in adult rams in the breeding season are associated with increases in key proteins in the testes which are known to be rate-limiting or highly regulated by LH. Substantial increases in StAR and P450scc mRNA and in $\mathrm{P} 40_{17 \alpha}$ activity may all contribute towards maintaining increased testosterone biosynthesis. Although these results provide some explanation for the seasonal rise in testosterone concentration (for example mean increase of $9.6 \mathrm{ng} \mathrm{m}^{-1}$ in control rams) the reasons for the comparable $\mathrm{LH}-$ 

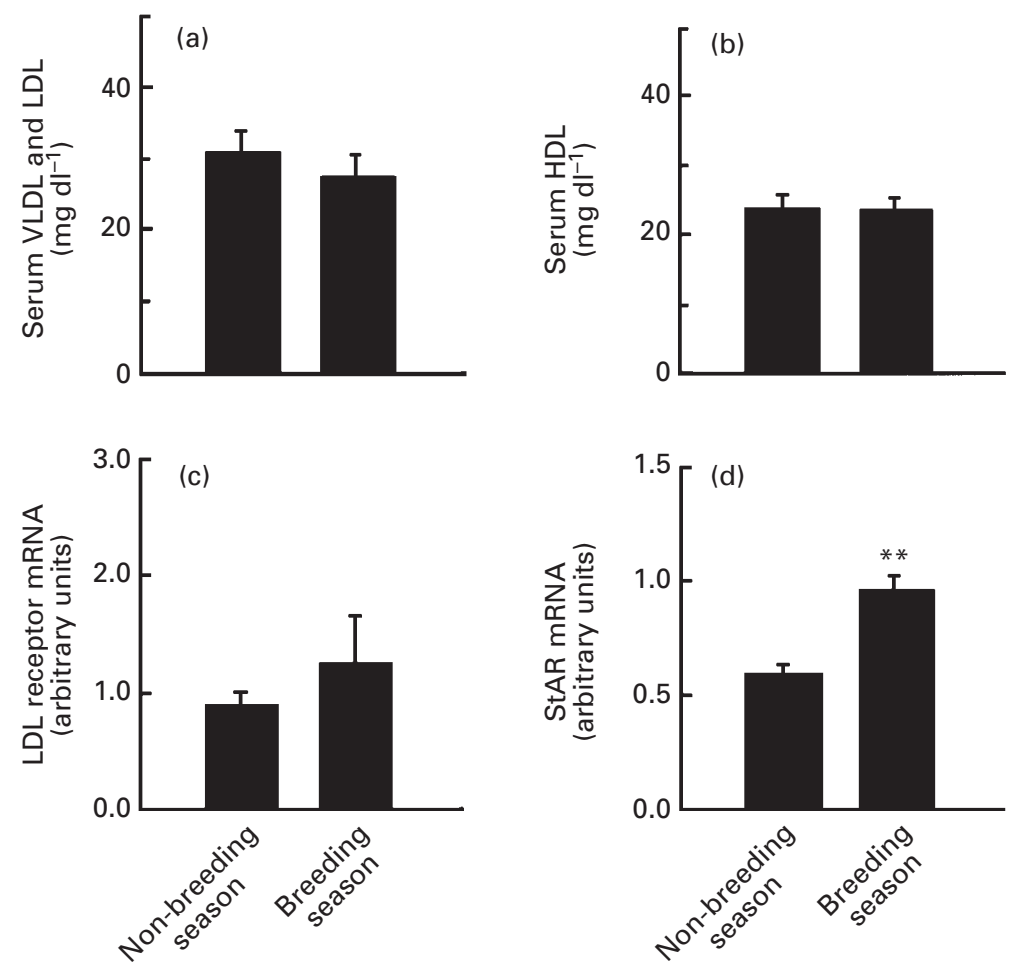

Fig. 4. Serum concentrations of combined very low and low density lipoprotein (VLDL and LDL) (a) and high density lipoprotein (HDL) (b) (day 21), and relative abundance of mRNA of the LDL receptor (c) and steroidogenic acute regulatory protein (StAR) (d) in testicular tissue (day 23) for control and oestradiol-immunized rams. Estimates of mRNA abundance were corrected for loading (pixel density of target probe divided by pixel density of 28S rRNA probe) and are expressed relative to a control sample included in all blots. Means ( \pm SEM) represent six or seven (non-breeding season) or eight (breeding season) rams. Asterisks indicate significant $\left({ }^{* *} P<0.01\right)$ differences between seasons.

Table 2. Correlation $(r)$ between parameters of episodic LH release and testicular steroidogenic acute regulatory protein (StAR) and steroidogenic enzyme mRNA concentration and enzyme activity in rams ${ }^{\mathrm{a}}$

\begin{tabular}{|c|c|c|c|c|c|c|}
\hline \multirow[b]{2}{*}{ LH parameter } & \multirow[b]{2}{*}{ StAR mRNA } & \multicolumn{2}{|c|}{ Enzyme RNA } & \multicolumn{3}{|c|}{ Enzyme activity } \\
\hline & & P450scc & $\mathrm{P} 450_{17 \alpha}$ & $\mathrm{P} 450_{17 \alpha}$ & $3 \beta-H S D$ & $17 \beta-H S D$ \\
\hline Mean $^{\text {b }}$ & $0.73^{* *}$ & $0.70^{* *}$ & 0.07 & $0.82^{* * *}$ & 0.08 & 0.24 \\
\hline Basal $^{\mathrm{c}}$ & $0.71^{* *}$ & $0.70^{* *}$ & 0.08 & $0.81^{* * *}$ & 0.11 & 0.24 \\
\hline Frequency ${ }^{\mathrm{d}}$ & $0.76^{* *}$ & $0.81^{* * *}$ & 0.01 & $0.90^{* * *}$ & -0.04 & 0.02 \\
\hline Amplitude $^{\mathrm{e}}$ & 0.44 & 0.33 & 0.05 & 0.43 & 0.12 & -0.33 \\
\hline
\end{tabular}

aPearson or Spearman (pulse frequency) correlation coefficients representing the four groups of rams; asterisks indicate levels of significance $\left({ }^{* *} P<0.01,{ }^{* * *} P<0.001\right)$.

${ }^{b}$ Mean LH concentration over the $8 \mathrm{~h}$ sampling period.

Interpulse LH concentration with blood sampling every $20 \mathrm{~min}$.

dNumber of LH pulses per $8 \mathrm{~h}$.

ePeak LH concentration minus preceding nadir.

33-HSD: $3 \beta$-hydroxysteroid dehydrogenase $/ \Delta^{5}-\Delta^{4}$ isomerase; $17 \beta$-HSD: $17 \beta$-hydroxysteroid dehydrogenase.

independent increases in testosterone with oestradiol immunization (for example mean increase of $8.6 \mathrm{ng} \mathrm{ml}^{-1}$ in the breeding season) remain obscure. Increases in StAR mRNA and 17 $\beta$-HSD activity were small and probably do not explain fully how low-level oestradiol immunization led to increased testosterone secretion in rams. It is concluded that other as yet unidentified oestradiol actions within the testis may also be involved.
As the testes of adult rams undergo recrudesence in the summer, the volume and possibly number of Leydig cells increase (Garnier et al., 1981; Hochereau-de Reviers et al., $1985,1992)$. Increased blood testosterone concentration in the breeding season relates to a greater total volume of Leydig cells per testis and cross-sectional area of Leydig cells (Hochereau-de Reviers et al., 1985). In seasonally breeding males, increased steroidogenic capacity of Leydig cells in 
Table 3. Correlation $(r)$ between parameters of testosterone synthesis and testicular steroidogenic acute regulatory protein (StAR) mRNA concentration and steroidogenic enzyme activities in rams

\begin{tabular}{|c|c|c|c|c|}
\hline \multirow[b]{2}{*}{ Testosterone parameter } & \multirow[b]{2}{*}{ StAR mRNA } & \multicolumn{3}{|c|}{ Enzyme activity } \\
\hline & & $\mathrm{P} 450_{17 \alpha}$ & $3 \beta-H S D$ & $17 \beta-H S D$ \\
\hline Mean $^{\mathrm{b}}$ & $0.86^{* * *}$ & $0.82^{* * *}$ & 0.22 & 0.16 \\
\hline Basal $^{c}$ & $0.85^{* * *}$ & $0.82^{* * *}$ & 0.16 & 0.40 \\
\hline Stimulated $^{\mathrm{d}}$ & $0.84^{* * *}$ & $0.74^{* *}$ & 0.15 & 0.12 \\
\hline
\end{tabular}

apearson correlation coefficients representing the four groups of rams; asterisks indicate levels of significance $\left({ }^{* *} P<0.01,{ }^{* * *} P<0.001\right)$.

${ }^{b}$ Mean testosterone concentration over the $8 \mathrm{~h}$ sampling period.

'Interpulse testosterone concentration with blood sampling every $20 \mathrm{~min}$.

${ }^{\mathrm{d}}$ Area under the $2 \mathrm{~h}$ testosterone response curve (above time 0 concentration) to a single physiological injection of NIH-LH-S25.

$3 \beta$-HSD: $3 \beta$-hydroxysteroid dehydrogenase $/ \Delta^{5}-\Delta^{4}$ isomerase; $17 \beta$-HSD: $17 \beta$-hydroxysteroid dehydrogenase.

reactivated testes is associated with more highly developed mitochondria and smooth endoplasmic reticulum (Lincoln, 1989), which in rams can be as much as three times more abundant (Mortimer and Lincoln, 1982). In the present study, testosterone mean concentration and total response to $\mathrm{LH}$ injection were more than six- and 2.5-fold greater in the breeding season than in the non-breeding season. It was confirmed that, as in males of closely related ruminants such as deer (Bilinska, 1985) and goats (Mori et al., 1980), testosterone biosynthesis involves the 5-ene pathway (Fields et al., 1980), which predominates irrespective of season.

Episodic testosterone secretion in rams is tightly coupled to episodic LH release (Pelletier et al., 1982; Lincoln, 1989). Evidence indicates that increases in LH pulse frequency are largely responsible for the seasonal increases in testosterone secretion. Monthly changes in LH pulse frequency and mean testosterone concentration are highly correlated (Sanford et al., 1977), and experimentally increasing LH pulse frequency during testicular recrudesence increases blood testosterone concentration by 3.5-fold within days (Sanford and Baker, 1990; Melnyk et al., 1992). Increases in basal (interpulse) LH concentration (Chase et al., 1988) and in the number of testicular LH receptors (Barenton and Pelletier, 1983) likely combine with increases in LH pulse frequency to increase the steroidogenic capacity and responsiveness of Leydig cells to $\mathrm{LH}$ in the breeding season. In rams in the present study, seasonal increases in LH release (pulse frequency, mean and basal concentrations) were strongly related to corresponding increases in $\mathrm{P} 450_{17 \alpha}$ activity and to a lesser extent in the amount of P450scc mRNA in the testis. Although LH is necessary for expression of all four enzymes involved in testosterone biosynthesis, only $\mathrm{P}_{450} 0_{17 \alpha}$ expression in mice (Payne and Youngblood, 1995) and P450scc and P450 expression in rats (Saez, 1994) are highly dependent upon LH. Whether there is a causal relationship between specific parameters of episodic LH release and the expression of these enzymes in rams, as implied by the results of the present study, remains to be determined.

Blood parameters of episodic testosterone secretion (mean and basal concentrations) and the testosterone response to an LH challenge were highly correlated with two key regulatory proteins in the testis, StAR (mRNA concentration) and $\mathrm{P} 50_{17 \alpha}$ (activity). In most biological systems investigated, StAR facilitates the delivery of cholesterol from the outer to the inner mitochondrial membrane and the P450scc enzyme, enabling greater conversion of cholesterol to pregnenolone (Stocco, 1997, 1998). Continuously high trophic stimulation of the testes of rams in the breeding season was associated with a $65 \%$ higher steady-state concentration of StAR mRNA, which presumably led to an increase in the synthesis of StAR protein since transcriptional and translational activity are normally tightly coupled (Stocco, 1997, 1998). In the present study, the several-fold increases in testicular steroidogenesis with season would not have been possible without greater de novo synthesis of StAR, known to be the rate-limiting step in LH-induced testosterone production (Stocco, 1997, 1998). However, it should be noted that StAR transcription and translation occasionally can be dissociated (Clark and Stocco, 1997) and that $10-20 \%$ of the steroidogenic potential of Leydig cells may be StAR independent (Clark et al., 1997). Testicular proteins other than StAR may also be involved in regulating cholesterol transport (Stocco, 1998). Thus, precise relationships among StAR mRNA and protein expression and testosterone production need to be established in rams, as does the significance of the $65 \%$ seasonal increase in P450scc mRNA; the activity of P450scc was not measured.

The second testicular protein that was highly correlated with blood testosterone parameters was $\mathrm{P} 40_{17 \alpha}$. The activity of this enzyme was more than fivefold higher in the breeding season than in the non-breeding season. This enzyme plays a key regulatory role in species in which the 5-ene pathway predominates by competing with $3 \beta-\mathrm{HSD}$ and directing pregnenolone metabolism towards DHEA (Conley and Bird, 1997). $\mathrm{P} 450_{17 \alpha}$ is highly responsive to $\mathrm{LH}$, at least in rodent species (Saez, 1994; Payne and Youngblood, 1995) and thus might also be expected to play an important role in regulating the seasonal changes in testosterone biosynthesis as the trophic stimulation to Leydig cells changes. The results of the present study indicate that this may be true for rams since the activity of $\mathrm{P}^{4} 50_{17 \alpha}$ increased in proportion to mean testosterone concentration in the breeding season whereas the activities of $3 \beta-H S D$ and $17 \beta-H S D$ remained the same. These observations also indicate that the last two enzymes in the biosynthetic pathway were not rate limiting. Alterations in testosterone metabolism within the testes were probably not responsible for differences in blood testosterone concentrations between groups of rams since concentrations of 
testosterone $5 \alpha$-reductase and cytochrome P450 aromatase were very low (both were undetectable, data not presented). Finally, greater activity of $\mathrm{P} 450_{17 \alpha}$ in the breeding season was not associated with a simultaneous increase in mRNA transcript for this enzyme, perhaps because of differences in the half-life of enzyme protein and mRNA or because other mechanisms were directly regulating enzyme activity per se.

Low-level oestradiol immunoneutralization for 3 weeks produced increases in various parameters of episodic testosterone secretion in rams which, in the breeding season, were equivalent in value to seasonal increases in controls. Differences in blood testosterone concentration between immunized and control rams most likely reflect differences in testosterone secretion. Schanbacher et al. (1987) showed that when rams are actively immunized against oestradiol, testosterone metabolic clearance rate does not change and tenfold increases in testosterone mean concentration are in proportion to the estimated daily production rate. The results of the present study demonstrate that twofold increases in testosterone at much lower titres of oestradiol antibody are not an artefact of antiserum administration, since neither the capacity of serum to bind labelled testosterone nor the displacement of serum-bound testosterone by oestradiol increased with immunization.

Increases in testosterone secretion in immunized rams occurred independently of increases in any of the parameters of episodic LH release, as has been observed with low titres (approximately 1:100-200) of oestradiol antibody developed and maintained over 2-4 weeks (Sanford, 1985, 1987b, 1989; Sanford et al., 1991). In the absence of a change in trophic stimulation, a reasonable explanation for the testosterone increases with immunization is that there was a reduction in oestradiol negative feedback action within the testes. Oestradiol antibody could easily have penetrated postcapillary venules and entered interstitial fluid (Bergh and Damber, 1993) and subsequently bound a portion of the 'free' available oestradiol diffusing in either from Leydig cells (Bilinska et al., 1997) or Sertoli cells (Bardin et al., 1994). The end result may have been a reduction in effective oestradiol concentration (Hillier et al., 1975; Wickings and Nieschlag, 1978) in the vicinity of Leydig cells.

Oestradiol immunization was associated with a $20 \%$ increase in the abundance of StAR mRNA. Northern blot analysis of StAR transcripts in mouse Leydig tumour cells stimulated with hCG showed that relatively small increases in StAR transcription can be meaningful physiologically (Manna et al., 1999). However, it is difficult to see how StAR requirement for the near doubling of testosterone secretion in immunized rams in the breeding season could have been met by such a small increase in transcription, unless reducing oestradiol action in the testis resulted in more complete StAR translation, which is proposed to be differentially regulated (Clark and Stocco, 1997). It has been reported that oestradiol stimulates rather than depresses StAR expression in the rabbit corpus luteum (Townson et al., 1996) and in pig granulosa cells (Chedrese et al., 1996). The only other protein change in the testes of immunized rams was a relatively small increase in $17 \beta-H S D$ activity, which may have facilitated testosterone biosynthesis by increasing androstenedione metabolism. It is possible that oestrogen affected $\mathrm{P}_{450_{17 \alpha}}$ and $3 \beta$-HSD, but that these effects were negated by induction of a testosterone autoregulation mechanism which, as in mice (Payne and Youngblood, 1995), limits the synthesis or activities of these enzymes at high testosterone concentrations.

Season and oestradiol immunization did not affect blood cholesterol lipoprotein concentrations or testicular LDL-R mRNA. In the present study, cholesterol was fairly evenly distributed between combined VLDL and LDL (54\%) and HDL $(46 \%)$ fractions. This is in contrast to previous reports showing that much more of the plasma cholesterol in sheep is in either the LDL or the HDL fraction (Vitic and Stevanovic, 1993; Meyer et al., 1996). Both LDL and HDL support steroidogenesis in ovine adrenal and luteal cells in vitro (Durand et al., 1987; Rainey et al., 1988; Wiltbank et al., 1990) and in Leydig cells in rodent species (Saez, 1994). However, steroidogenic activity is not correlated with LDL-R or HDL binding protein in corpora lutea in ewes (Tandeski et al., 1996) or with blood lipoprotein concentrations or testicular LDL-R mRNA in rams (present study). These observations indicate that changes in lipoprotein receptor dynamics were not part of the mechanism or mechanisms regulating gonadal steroidogenesis in the present study.

The correlative results of the present study strongly imply that in the testes of adult rams: (i) StAR and $\mathrm{P} 450_{17 \alpha}$ may have central roles in regulating the LH-driven seasonal increases in testosterone biosynthesis; and (ii) that StAR and 17 $\beta-H S D$ may help facilitate LH-independent increases in testosterone secretion with oestradiol immunization. Other intratesticular regulatory factors affected by oestradiol, possibly from Sertoli cells or germ cells, which in rats contain oestrogen receptor $\beta$ (Saunders et al., 1998; van Pelt et al., 1999), may also be involved. These hypotheses remain to be tested.

The authors thank D. G. Leggee, K. Soumano and R. S. T. Squire for technical assistance, C. Wilson for caring for the rams, and B. Sutherland for veterinary assistance in gonadectomizing the rams. The authors gratefully acknowledge the NIDDKD for providing LH preparations, and D. Stocco and M. R. Waterman for donating cDNA probes (as indicated in the text). Rams were kindly provided by M. H. Fahmy, Agriculture and Agri-Food Canada, Lennoxville, Québec. This research was funded by the Natural Sciences and Engineering Research Council of Canada.

\section{References}

Bardin CW, Cheng CY, Mustow NA and Gunsalus GL (1994) The Sertoli cell. In The Physiology of Reproduction Vol. 1, 2nd Edn pp 1291-1333 Eds E Knobil and JD Neill. Raven Press, New York

Barenton B and Pelletier J (1983) Seasonal changes in testicular gonadotropin receptors and steroid content in the ram Endocrinology 112 1441-1446

Bergh A and Damber J-E (1993) Vascular controls in testicular physiology. In Molecular Biology of the Male Reproductive System pp 439-468 Ed. D de Kretser. Academic Press, New York

Bilinska B (1985) Hormonal secretion and enzyme activity of cultured roe-deer (Capreolus capreolus L.) Leydig cells, as measured by radioimmunological and histochemical assays Cytobios 44 29-39

Bilinska B, Lesniak M and Schmalz B (1997) Are ovine Leydig cells able to aromatize androgens? Reproduction, Fertility and Development 9 193-199

Chase DJ, Schanbacher BD and Lunstra DD (1988) Effects of pulsatile and continuous luteinizing hormone (LH) infusions on testosterone responses to LH in rams actively immunized against gonadotropin-releasing hormone Endocrinology 123 816-826 
Chedrese PJ, Stocco DM and Braileanu GT (1996) FSH, LH and estradiol$17 \beta\left(E_{2}\right)$ stimulates steroidogenic acute regulatory (StAR) protein-gene expression in cultured porcine granulosa cells Biology of Reproduction $\mathbf{5 4}$ Supplement 1 Abstract 75

Clark BJ and Stocco DM (1997) Steroidogenic acute regulatory protein: the StAR still shines brightly Molecular and Cellular Endocrinology 134 1-8

Clark BJ, Wells J, King SR and Stocco DM (1994) The purification, cloning and expression of a novel LH-induced mitochondrial protein in MA-10 mouse Leydig tumor cells: characterization of the steroidogenic acute regulatory protein (StAR) Journal of Biological Chemistry $26928314-28322$

Clark BJ, Combs R, Hales KH, Hales DB and Stocco DM (1997) Inhibition of transcription affects synthesis of steroidogenic acute regulatory protein and steroidogenesis in MA-10 mouse Leydig tumor cells Endocrinology 138 4893-4901

Cleland WW (1967) The statistical analysis of enzyme kinetic data Advances in Enzymology 29 1-32

Conley AJ and Bird IM (1997) The role of cytochrome P450 17 $\alpha$-hydroxylase

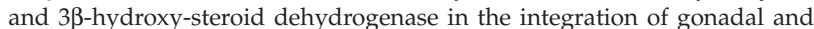
adrenal steroidogenesis via the $\Delta^{5}$ and $\Delta^{4}$ pathways of steroidogenesis in mammals Biology of Reproduction 56 789-799

Cooke GM (1991) Steroidogenesis in interstitial cells and microsomal fraction of immature pig testes Journal of Reproduction and Fertility 91 175-185

Cooke GM, Price CA and Oko RJ (1998) Effects of in utero and lactational exposure to 2,3,7,8-tetrachlorodibenzo-p-dioxin (TCDD) on serum androgens and steroidogenic enzyme activities in the male rat reproductive tract Journal of Steroid Biochemistry 67 347-354

Darbeïda H and Brudieux R (1980) Seasonal variations in plasma testosterone and dihydrotestosterone levels and in metabolic clearance rate of testosterone in rams in Algeria Journal of Reproduction and Fertility 59 229-235

Durand P, Cathiard A-M, Naaman E, Brieu V and Saez JM (1987) The influence of plasma lipoproteins on steroidogenesis of cultured ovine fetal and neonatal adrenal cells Journal of Steroid Biochemistry 26 425-431

Fahmy MM and Dufour JJ (1986) The breeding season and ovulation rate of DLS ewes as determined by laparoscopy Canadian Journal of Animal Science 66 297-301

Fields MJ, Beverly RJ and Fleeger JL (1980) Incorporation of $\left[1-{ }^{14} \mathrm{C}\right]$-acetate into testosterone, androstenediol, dehydroepiandrosterone and progestogens by ram testis following human chorionic gonadotropin administration Theriogenology 14 433-441

Freeman DA (1985) Estradiol acts as a competitive inhibitor of the $3 \beta$ hydroxysteroid dehydrogenase $/ \Delta^{5}-\Delta^{4}$ isomerase enzyme of cultured Leydig tumor cells Endocrinology 117 2127-2133

Garnier DH, Hochereau-de Reviers MT, Pelletier J, Ravault JP, Courot M and Terqui M (1981) LH, prolactin, testosterone, testis weights and Leydig cells in the adult normal ram during the breeding season International Journal of Andrology Supplement 3 44-45

Hillier SG, Groom GV, Boyns AR and Cameron EHD (1975) The active immunisation of intact adult rats against steroid-protein conjugates: effects on circulating hormone levels and related physiological processes. In Steroid Immunoassay pp 97-110 Eds EHD Cameron, SG Hillier and K Griffiths. Alpha Omega Publishing, Cardiff

Hochereau-de Reviers MT, Perreau C and Lincoln GA (1985) Photoperiodic variations of somatic and germ cell populations in the Soay ram testis Journal of Reproduction and Fertility 74 329-334

Hochereau-de Reviers MT, Perreau C, Pisselet C and Pelletier J (1992) Effect of a 2-month light cycle regimen on testicular parameters of adult Ile-deFrance rams Microscopy Research and Technique 20 268-273

Hötzel MT, Markey CM, Walkden-Brown SW, Blackberry MA and Martin GB (1998) Morphometric and endocrine analyses of the effects of nutrition on the testis of mature Merino rams Journal of Reproduction and Fertility 113 217-230

Hurden EL, Gower DB and Harrison FA (1984) Comparative rates of formation in vivo of 16-androstenes, testosterone and androstenedione in boar testis Journal of Endocrinology 103 179-186

John ME, John MC, Ashley P, MacDonald RJ, Simpson ER and Waterman MR (1984) Identification and characterization of cDNA clones specific for cholesterol side-chain cleavage cytochrome P-450 Proceedings National Academy of Sciences USA 81 5628-5632

Lincoln GA (1989) Seasonal aspects of testicular function. In The Testis 2nd Edn pp 329-385 Eds H Burger and D de Kretser. Raven Press, New York

Lowry OH, Rosebrough NJ, Farr AL and Randall RJ (1951) Protein measurement with the Folin phenol reagent Journal of Biological Chemistry $193265-271$
Lunstra DD and Schanbacher BD (1988) Testicular function and Leydig cell ultrastructure in long-term bilaterally cryptorchid rams Biology of Reproduction 38 211-220

Manna PR, Pakarinen P, El-Hefnawy T and Huhtaniemi IT (1999) Functional assessment of the calcium messenger system in cultured mouse Leydig tumor cells: regulation of human chorionic gonadotropin-induced expression of the steroidogenic acute regulatory protein Endocrinology 140 1739-1751

Majdic G, Sharpe RM, O'Shaughnessy PJ and Saunders PTK (1996) Expression of cytochrome P450 17 $\alpha$-hydroxylase/C17-20 lyase in the fetal rat testis is reduced by maternal exposure to exogenous estrogens Endocrinology 137 1063-1070

Markwald RR, Davis RW and Kainer RA (1971) Histological and histochemical periodicity of cervine Leydig cells in relation to antler growth General and Comparative Endocrinology 16 268-280

Melner MH and Abney TO (1980) The direct effect of 17ß-estradiol on LHstimulated testosterone production in hypophysectomized rats Journal of Steroid Biochemistry 13 203-210

Melnyk PM, Sanford LM and Robaire B (1992) Moderate increases in peripheral blood estradiol concentration in the adult ram do not directly inhibit testosterone secretion Canadian Journal of Physiology and Pharmacology $701384-1391$

Meyer HH, Abdulkhaliq A, Davis SL, Thompson J, Nabioullin R, Wu P-Y and Forsberg NE (1996) Effects of the Callipyge phenotype on serum creatinine, total cholesterol, low-density lipoproteins, very-low-density lipoproteins, high-density lipoproteins, and triacylglycerol in growing lambs Journal of Animal Science 74 1548-1552

Moger WH (1980) Direct effects of estrogens on the endocrine function of the mammalian testis Canadian Journal of Physiology and Pharmacology 58 1011-1022

Mori M, Matsukura S, Kawakura K and Tamaoki B-I (1980) In vitro synthesis of androgen from pregnenolone in the testes of the goat (Capra hircus) and identification of 5-pregnene-3 $\beta, 17 \alpha, 20 \alpha$-triol as an intermediate in the metabolic pathway of pregnenolone Journal of Endocrinology 84 381-390

Mortimer D and Lincoln GA (1982) Ultrastructural study of regressed and reactivated testes from Soay rams Journal of Reproduction and Fertility 64 $437-442$

Niswender GD, Reichert LE, Jr, Midgley AR, Jr and Nalbandov AV (1969) Radioimmunoassay for bovine and ovine luteinizing hormone Endocrinology 84 1166-1173

Nozu K, Dufau ML and Catt KJ (1981) Estradiol receptor-mediated regulation of steroidogenesis in gonadotropin-desensitized Leydig cells Journal of Biological Chemistry 256 1915-1922

Payne AH and Youngblood GL (1995) Regulation of expression of steroidogenic enzymes in Leydig cells Biology of Reproduction 52 217-225

Pelletier J, Garnier DH, de Reviers MM, Terqui M and Ortavant R (1982) Seasonal variation in $\mathrm{LH}$ and testosterone release in rams of two breeds Journal of Reproduction and Fertility 64 341-346

Rainey WE, Viard I, Mason JI, Cochet C, Chambaz EM and Saez JM (1988) Effects of transforming growth factor beta on ovine adrenocortical cells Molecular and Cellular Endocrinology 60 189-198

Russell DW, Schneider WJ, Yamamoto T, Lusley KL, Brown MS and Goldstein JL (1984) Domain map of the LDL receptor: sequence homology with the epidermal growth factor precursor Cell 37 577-585

Saez JM (1994) Leydig cells: endocrine, paracrine and autocrine regulation Endocrine Reviews 15 574-626

Saunders PTK, Fisher JS, Sharpe RM and Millar MR (1998) Expression of oestrogen receptor beta $(\mathrm{ERb})$ occurs in multiple cell types, including some germ cells, in the rat testis Journal of Endocrinology 156 R13-R17

Sanford LM (1985) Evidence that estrogen regulation of testosterone secretion in adult rams is mediated by both indirect (gonadotropin dependent) and direct (gonadotropin independent) means Journal of Andrology 6 306-314

Sanford LM (1987a) Luteinizing hormone release in intact and castrate rams is altered with immunoneutralization of endogenous estradiol Canadian Journal of Physiology and Pharmacology 65 1442-1447

Sanford LM (1987b) Seasonal variation in circulating gonadotropin and testosterone levels and in testis size of yearling rams during and subsequent to immunoneutralization of estradiol or tamoxifen treatment in the nonbreeding season Canadian Journal of Animal Science 67 391-404

Sanford LM (1989) Increases in testosterone secretion in adult rams with immunoneutralization of endogenous estradiol occur in the absence of increases in pulsatile LH release or testicular LH receptors Acta Endocrinologica (Copenhagen) 120 180-186 
Sanford LM and Baker SJ (1990) Enhanced testosterone secretion in adult rams after establishment of a high-frequency, low-amplitude pattern of LH pulses in the nonbreeding season occurs without changes in the number or binding affinity of testicular LH receptors Acta Endocrinologica (Copenhagen) $12255-61$

Sanford LM and Robaire B (1990) Interaction of season and estradiol in the regulation of gonadotropin secretion in the ram Canadian Journal of Physiology and Pharmacology 68 150-156

Sanford LM, Palmer WM and Howland BE (1977) Changes in the profiles of serum LH, FSH and testosterone, and in mating performance and ejaculate volume in the ram during the ovine breeding season Journal of Animal Science 45 1382-1391

Sanford LM, Howland BE and Palmer WM (1984) Seasonal changes in the endocrine responsiveness of the pituitary and testes of male sheep in relation to their patterns of gonadotropic hormone and testosterone secretion Canadian Journal of Physiology and Pharmacology 62 827-833

Sanford LM, Leggee DG and Melnyk PM (1991) Maintaining a high physiological rate of testosterone secretion in the adult ram by estradiol immunoneutralization partially prevents testicular regression Canadian Journal of Animal Science 71 1099-1109

Sanford LM, Voglmayr JK, Vale WW and Robaire B (1993) Photoperiodmediated increases in serum concentrations of inhibin, follicle-stimulating hormone, and luteinizing hormone are accentuated in adult shortenedscrotum rams without corresponding decreases in testosterone and estradiol Biology of Reproduction 49 365-373

SAS (1989) SAS/STAT User's Guide Version 6, 4th Edn, Statistical Analysis System Institute Inc., Cary, NC

Schanbacher BD, Pelletier J and Hochereau-de Reviers MT (1987) Follicle stimulating hormone, luteinizing hormones and testicular Leydig cell responses to estradiol immunization in Ile-de-France rams Journal of Andrology 8 97-102

Soumano K and Price CA (1997) Ovarian follicular steroidogenic acute regulatory protein, low-density lipoprotein receptor, and cytochrome P450 side-chain cleavage messenger ribonucleic acids in cattle undergoing superovulation Biology of Reproduction 56 516-522

Stocco DM (1997) The steroidogenic acute regulatory (StAR) protein two years later Endocrine 6 1-11

Stocco DM (1998) A review of the characteristics of the protein required for the acute regulatory steroid hormone biosynthesis: the case for the steroidogenic acute regulatory (StAR) protein (44214) Proceedings of the Society of Experimental Biology and Medicine 217 123-129

Tandeski TR, Juengel JL, Nett TM and Niswender GD (1996) Regulation of mRNA encoding low density lipoprotein receptor and high density lipoprotein-binding protein in ovine corpora lutea Reproduction, Fertility and Development 8 1107-1114

Townson DH, Wang XJ, Keyes PL, Kostyo JL and Stocco DM (1996) Expression of the steroidogenic acute regulatory protein (StAR) in the corpus luteum of the rabbit: dependence upon the luteotropic hormone, 17ß-estradiol Biology of Reproduction 55 868-874

van Pelt AMM, de Rooij DG, van der Burg B, van der Saag PT, Gustafsson J-Å and Kuiper GGJM (1999) Ontogeny of estrogen receptor- $\beta$ expression in rat testis Endocrinology 140 478-483

Vitic J and Stevanovic J (1993) Comparative studies of the serum lipoproteins and lipids in some domestic, laboratory and wild animals Comparative Biochemistry and Physiology 106B 223-229

Wang C, Erickson G, Hopper B and Hsueh A (1980) Direct inhibitory effect of enclomiphene citrate and estradiol on testis functions in hypophysectomized rats Biology of Reproduction 22 645-653

Webb R, Land RB, Pathiraja N and Morris BA (1984) Passive immunization against steroid hormones in the female. In Immunological Aspects of Reproduction in Mammals pp 475-499 Ed. DB Crighton. Butterworths, London

Whitehead PE and West NO (1977) Metabolic clearance and production rates of testosterone at different times of the year in male caribou and reindeer Canadian Journal of Zoology 55 1692-1697

Wickings EJ and Nieschlag E (1978) Inhibition of testicular steroids by antibodies - a feasible approach to male contraception International Journal of Andrology Supplement 2384-390

Wiltbank MC, Diskin MG, Flores JA and Niswender GD (1990) Regulation of the corpus luteum by protein kinase C. II. Inhibition of lipoproteinstimulated steroidogenesis by prostaglandin $\mathrm{F}_{2 \alpha}$ Biology of Reproduction 42 239-245

Zuber MX, John ME, Okamura T, Simpson ER and Waterman MR (1986) Bovine adrenocortical cytochrome $\mathrm{P}-450_{17 \alpha}$ regulation of gene expression by ACTH and elucidation of primary sequence Journal of Biological Science $\mathbf{2 6 1}$ 2475-2482 